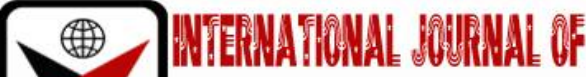

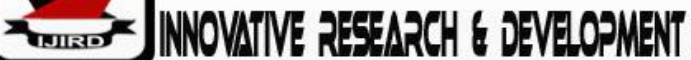

ISSN 2278-0211 (Online)

\section{Appraisal of Financial Inclusion Strategy through Access to Payment Terminals in Northern Nigeria}

\section{Idris Yahaya Adamu}

Lecturer, Department of Business Administration, Federal University Kashere, Nigeria

\begin{abstract}
:
This study explores the contributions of modern payment terminals towards increasing financial inclusion among individuals in northern Nigeria. The study used a qualitative approach to explore the experiences of informants about financial inclusion issues. The study used the purposive sampling strategy in data collection through in-depth interviews. The study used Nvivo10 in the analyses and revealed that NFIS drives economic development through enhanced access to financial services. Banks implement NFIS by ensuring access modern payment services in remote areas and by use of internet and mobile services. Despite all effort put by government to strengthen financial inclusion, some individuals are sceptical to using modern payment services. On the other hand, individuals face challenges of distance to service area, financial literacy and increasing charges for using payment terminals. These issues are impeding their access to payment terminals. This study identifies banks' impact on enhancing financial inclusion, shows the function and role of banks towards financial inclusion drive. The study increases entrepreneurs' awareness of financial services. Banks may use this study to predict clients' challenges and payments services. With this study, banks could also help financial regulators to redesign strategies towards modern payments and financial literacy.
\end{abstract}

Keywords: Access to payments, financial inclusion, ATMs POS, mobile and internet banking, and bank account

\section{Introduction}

Nigeria, like other AFI member countries set a target of reducing the extent of financial exclusion and increase inclusion to at least 80 percent of all individuals are having access to bank account and payment terminals by the year 2020 (Egbide, Samuel, Babajide, \& Samuel, 2015).

This target is necessary due to the need for a strong financial system and effective implementation of financial inclusion which are used to manage several macro and micro-economic activities (Asongu, \& De Moor, 2015). Therefore, one of the major responsibilities of financial service industry is to provide growth induced economic development (Abiara, \& Arosanyin, 2014), this aim may not be achieved without access to financial services. Individuals may have skill and experience of traditional finance, but, may lack knowledge of modern financial services as well as capital to start or to fund their activities (Akenbor, 2015). This necessitates central bank of Nigeria (CBN) to device means of improving access to financial services by all class of individuals.

Banks are the largest and most reliable source of financial services such as access to modern payment system, can offer financial facilities to individuals, only if they cannot lose depositors' funds. Meanwhile, since they are profit oriented financial service providers, they offer these services with little charges (Alabi, Lawal, \& Chiogor, 2016). This necessitates CBN and other financial institutions to implement various policies and programmes like National Financial Inclusion Strategy (NFIS) to enhance access to financial services.

Financial inclusion refers to an easy and convenient access to a broad range of affordable financial services that are designed to accommodate various needs of Nigerian adults (NFIS document, 2012). One of the cardinal objectives of NFIS is to ensure that, all individual adults in the country has access to financial services from formal financial sector of the economy (EFInA report, 2016). According to Beck, Demirguc-Kunt \& Honohap, (2008) financial inclusion is the ability of an individual or business enterprise to acquire suitable financial services from appropriate sources to meet the financial requisite for sustainable business and livelihood (Egbide, Samuel, Babajide, \& Samuel, 2015).

The NFIS documents shows that, access to savings are categorised into banked (those adults with at least access to savings account in DMB), formally served by other non-banks financial institutions (that is adults who have access to at least savings in financial institutions other than DMB), informally served (adults who have access to and use of financial services in any unregulated or informal financial institution like cooperative societies). The last category is excluded, i.e. adults without any form of financial savings product, formal or informal (NFIS document, 2012). 


\subsection{Objectives of the Study}

The broad objective of the study is to empirically appraise people's access to bank payment facilities in Nigeria towards the realisation of national financial inclusion strategy (NFIS) objectives. Specifically, to assess the following issues, from the actual stake holders (account holders) of financial inclusion:

- $\quad$ To appraise individuals' access and use of ATMs.

- $\quad$ To appraise individuals' access and use of POS and agent banking

- $\quad$ To appraise individuals' access and use of internet banking

- $\quad$ To appraise individuals' access and use of mobile banking

\subsection{Problem Statement}

The phenomenon of access to bank account and modern payment system is an issue confronting individuals and small businesses across the world as reflected by Beck \& Demirguc-Kunt (2008), in World Bank economic review, where they highlighted the alarming predicament of the degree of financial exclusion across the world. Beck \& Demirguc-Kunt (2008), realised that poor financial inclusion has a negative impact on individual welfare, enterprise growth, poverty reduction, income inequality control, and aggregate economic growth and development.

The low financial inclusion is a global issue, which resulted into the objective of achieving global financial inclusion agenda. In line with the global effort towards increasing financial inclusion, a summit was convened in Pittsburgh, USA in 2009 , with a target of increasing financial inclusion across the globe.

Jahiou (2013) also assert that some people are eligible to access financial services at convenient and affordable cost but may choose not to utilise some financial services, while others are lacking access to financial services due to some factors like cost, proximity, awareness/literacy, availability, regulation, procedure, culture, religious belief, or market structure.

NFIS strategy according to EFInA report, (2016) has a target of ensuring $60 \%$ of Nigerian adult have access to formal bank savings in 2020. To achieve this target (60\% target of 2020), it proposed compound asset growth rate (CAGR) target on savings of $11 \%$ between 2011 and 2020. The Actual growth in number of depositors for DMB's and MFB's between March 2013 and March 2014 is 12.23\%, and 25.36\% respectively. While for total value of deposits of DMBs and MFB's is $9.86 \%$ and $-4.09 \%$ respectively. Interestingly, it is likely for the savings target to be achieved, if the current growth rate is sustained. Meanwhile, the value of saving in MFB's supposed to be improved. The NFIS target on access to payments is to ensure $70 \%$ of Nigerian adults have access to and use of payments by 2020, with a proposed compound average growth rate (CAGR) target of 17\% per annum, between 2011 and 2020. There is a possibility for achieving the target of payments if innovations are expanded and sustained in power sector and internet connectivity.

\section{Literature review}

\subsection{Access to Commercial and Microfinance Banks' (MFB) Account}

Access to products of financial institutions is one of the universal indicators of financial inclusion extent. Individuals, households, or businesses are said to be financially included if they have unrestricted access to saving and payment in formal financial institutions (Rao, \& Baza, 2015).

Savings mobilisation by banks is usually the starting point of becoming financially inclusive society, financial institutions therefore, are to inculcate individuals the habit of saving. This is because, banks' effort to mobilise savings determine the extent of inclusion in a society. When Nigerian adults have at least savings account with formal financial institutions, it will open door for their access to other financial services like modern payment system (Rao, \& Baza, 2015). The number of deposit money banks (also known as commercial banks) as at 2016 were 21, serving 25M customers across 5,462 branches nationwide. The NFIS strategy put a target of 7.5 and 7.6 DMB branches per 100,000 adults by 2015 and 2020 respectively, but, the actual DMB branches as at 2015 is 5.7 per 100,000 adults. NFIS sets a target of $25 \%$ of those branches should be in remote and rural areas to serve people living outside the major cities, unfortunately, the target is far from being achieved (NFIS annual report, 2015). Globally, bank branches are found to be more concentrated in major cities and major towns than rural areas, due to banks' nature of business, meanwhile, to ensure access to financial services, there is need to increase access to financial services by rural and remote areas, which informs the establishment of microfinance banks, other microfinance institutions, and bank agents.

Microfinance policy framework (2005) was established due to failure of community banks to perform their expected role of rural community financing and failure of commercially oriented deposit money banks to reach various communities. Microfinance institutions serves 4.2M customers in 2,227 branches with $65 \%$ customers having savings account, $14 \%$ having credits and $4 \%$ using ATM cards, as at 2014. The NFIS target set for MFB branches was 4.5 and 5.0 for 2015 and 2020 per 100,000 adults respectively, but the actual number of branches as at 2015 is 4.2 per 100,000 adults (NFIS annual report, 2015). Instead of relying on DMB and MFB branches to extend financial services to rural areas, DMB prefer to extend financial services through electronic banking channels like ATMs, POS, mobile and internet banking, as discussed below:

\subsection{Access to Payments}

Access to modern payment systems is a good parameter of financial inclusion. The NFIS documents also show that, access to payments increases by increasing access to savings in deposit money banks. Access to payment system can also be formal, informal, and completely unserved by payments. Documents show low penetration of formal payments of $36 \%$ as at 2014, particularly mobile payments. Until recently, cash and cheque payments were dominantly used. With 
increased financial literacy and access to modern technology, ATMs, POS, mobile and internet banking are increasingly gaining acceptance and patronage among Nigerian banked adults (Egbide, Samuel, Babajide, \& Samuel, 2015).

Access to payments compliments having either current, savings, investment, fixed deposits account, or both, as well as access to channels of payment systems, like bank branches, electronic or online payment terminals (Malaguti, 2015). Access to payments is the broader sense of access to financial services, because it involves access to and use of channels of delivering financial services to make or receive funds transfer, even not having a bank account. For instance, a farmer who can make or receive mobile money transfer has access to payments even without operating a bank account. Meanwhile, access to payments in this research is considered as having access through DMB account, and the extent to which individual uses payment terminals like ATM, POS, internet, and mobile banking, as linked to his bank account.

The NFIS target on access to payments is to ensure $70 \%$ of Nigerian adults have access to and use of payments by 2020 . There is a possibility for achieving the target of payments if innovations are expanded and sustained in power sector and internet connectivity.

Access to payment system enables efficient flow of financial resources from one section of the economy to the other or between individuals. Payments are facilitated using various forms of financial instruments and electronic facilities, as aided by modern technological system. Efficient payment systems through increased access points is a good parameter of financial inclusion. It specifically supports flow of resources to and within agricultural value chain, which aids small holder farmers into broader access to financial services like credit, increased income, and market information. Over the years, financial institutions in collaboration with switch operators and internet and mobile network operators are increasingly paying more attention to branchless banking services (Richard Aborisade, 2014).

Financial inclusion can be improved through the effort of mobile money agents who provide payments through mobile phones and internet banking. They are usually petty traders and recharge card vendors, who consider mobile banking as source of additional income in form of commission without additional or overhead cost. The services they render include online bank account opening or registration, funds transfers, air time top-up, cash in deposit, cash withdrawal and utility bill payments. Even-though, the commission they earn is not much, but, they do the business without inconveniences in their shops and they see a future prospect in it, and the more customers an agent registers, the more incentives he receives from mobile money operators (MMOs). The agents earn commission through rebalancing of their float with the mobile operators occasionally, or through their banks, super agents, representatives, internet banking or direct to main office of the MMOs.

\subsubsection{Automated Teller Machines (Atms)}

There is widespread installation of Automated Teller Machines, in Nigerian towns. Actual growth between March 2013 and March 2014 shows an increase in volume of ATM transactions of 19.63\%, and more that 10,000 ATMs are installed in Nigerian market as at 2016. Banks usually install ATMs at their branches, market areas, public buildings, or busy streets. Apart from market, banks also consider security while installing ATMs in a particular location. There has been an increase in ATMs deployment between 2013 to 2014 of up to 28.33\%, this however, may not be unconnected with the increase in incentives as set by CBN. Despite all its challenges like poor internet connectivity, queue or dispense error, people prefer using ATMs than bank hall (over the counter) to perform transactions. ATMs are used more often for cash withdrawal than other services like cash transfer, bills payment, account balance enquiry, mobile phone recharge, and cash deposits. Meanwhile, small entrepreneurs are also using ATMs (NFIS annual report, 2015). However, like bank branches, customer must travel to ATMs location to perform a transaction. Unlike POS, where transaction can be made at vendor's business location.

\subsubsection{Point of Sales Terminals (POS) and Agent Banking}

Point of sales machines are small electronic instruments that are tailored to enable transfer of money from customers' account to sellers' (vendor's) account. As at 2015, about 15,000 POS machines are in place among Nigerian vendors. There has been an actual growth in volume for POS transactions by 193\% between 2013 and 2014 alone. Rate of POS terminals' deployment also increase by 5.87\% among Nigerian traders, during the same period (NFIS annual report, 2015). Meanwhile, with the advent of smart phones, there is no need to visit vendor's location to make payments, which enhances the need of mobile and internet banking system.

\subsubsection{Mobile and Internet Banking System}

Mobile and internet banking system enables individuals to make cashless computer-based transactions (Amidzic, Massara, and Mialou, 2014). Banks usually handle electronic payment system mechanism, in collaboration with private payment companies, and or inter-switch companies like e-Transact, Master-card, Visa, Verve, and Quick-teller and many others. "Inter-Switch" is an agent for online electronic transactions infrastructure for processing payment, it connects several payment channels, enables payment processing to payment platforms. Telecommunication companies presently are involved in respect to enhancing electronic payment systems with several operators. Prominent mobile network operators presently available in all towns and main roads across the country are: Airtel, Etisalat, Glo-mobile, and MTN.

There are several mobile money operators (MMO) across the country serving electronic banking system. Last figure shows an actual growth of MMOs customers by $0.13 \%$ and an increase of MMOs transaction volume by $116.45 \%$, as well as increased deployment for mobile money subscribers' access by $36.40 \%$. Despite lack of regulation on agent banking, there has been an increased number of mobile money agents to 64.98\%, all between 2013 and 2014. Despite emergence of other platforms for internet banking transfer services, Nigerian inter-bank settlement system (NIBSS) alone has increased volume for electronic transfers by 5.9\% (Amidzic, Massara, and Mialou, 2014). 


\section{Methodology}

Inductive research design was applied as a series of logical activities that connect the overall empirical data by observing phenomena, developing, and analysing patterns and themes to formulate a relationship, then develop theory in conclusions. The research design of this study encompasses analysis of some issues that are assumed to affect individuals' perspective of the process of access to financial services, on the course of being financially included (Creswell, 2013).

Exploratory is the major intent (the purpose) of this study, because, it aims to explore participants' views with the intent of using these views to develop a theory. Inductive research is innately exploratory in nature (Creswell, 2012). Thus, this research is a qualitative method with exploratory purpose of identifying important issues in financial inclusion from multiple informants' perspective.

In this research study, non-probability purposive sampling is used to select interview participants. Purposive sampling is appropriate when a researcher is selecting informants with some important features or characteristics, from extreme situations. The researcher realised that, it is better to purposively select informants that have knowledge of the population, elements, phenomena, and capable of providing information required, based on the aims of the research (Marshall \& Rossman, 1999).

Access to bank account services here means, getting access to financial services from banks. Banked individuals are categorised into having access to banking services and those not having access to banking services. In this paper, the responses to the interview are challenges and way out of the challenges for people accessing modern banking services, as well as account officers' effort to ensure access to modern banking services.

Although, NFIS document categorised access to financial services into; financially served and financially excluded, and the financially served are also categorised into; formally served (banked and formal other) and informally served, as simply illustrated in figure 3.2 below:

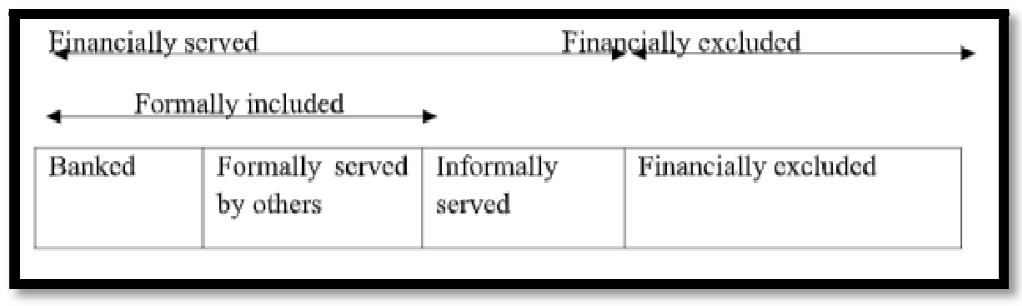

Figure 1: Inclusion and Exclusion as Defined by NFIS

Meanwhile, access to financial services in this research, is categorised into banked agribusiness entrepreneurs, i.e. having bank account in DMBs as financially served and unbanked agribusiness entrepreneurs as financially excluded, since we are concerned in access to financial services in DMB as our unit of data collection and analysis. DMB are the most important source of access to financial services to small-scale agribusiness entrepreneurs, which is simplified as illustrated in figure 3.3 below:

\begin{tabular}{l}
\hline \multicolumn{3}{|c|}{ Financially served } \\
\begin{tabular}{|l|l|l|}
\hline Banked but not accessing & Banked and accessing & Unbanked \\
modern financial services & modern rinancial & (6 participants) \\
(6 participants) & services (6 participants) & (6) \\
\hline
\end{tabular}
\end{tabular}

Figure 2: Inclusion and Exclusion as Defined In This Research

The illustration above reflects the number of clients interviewed as categorised into banked (18 participants) and Unbanked (6 participants).

\section{Findings}

\subsection{Entrepreneurs' Access to Bank Account}

Access to banks account refers to having at least savings account with deposit money (commercial) banks. Informants are categorised into two (2), those having bank account and those who do not have a bank account. Those who do not have a bank account were asked to express issues related to financial exclusion (bank exclusion) challenges. While, informants having bank account were asked to explain how frequent they use electronic payment channels to determine their extent of inclusion. Figure 3 shows the two (2) categories of informants as included and exclude entrepreneurs. 


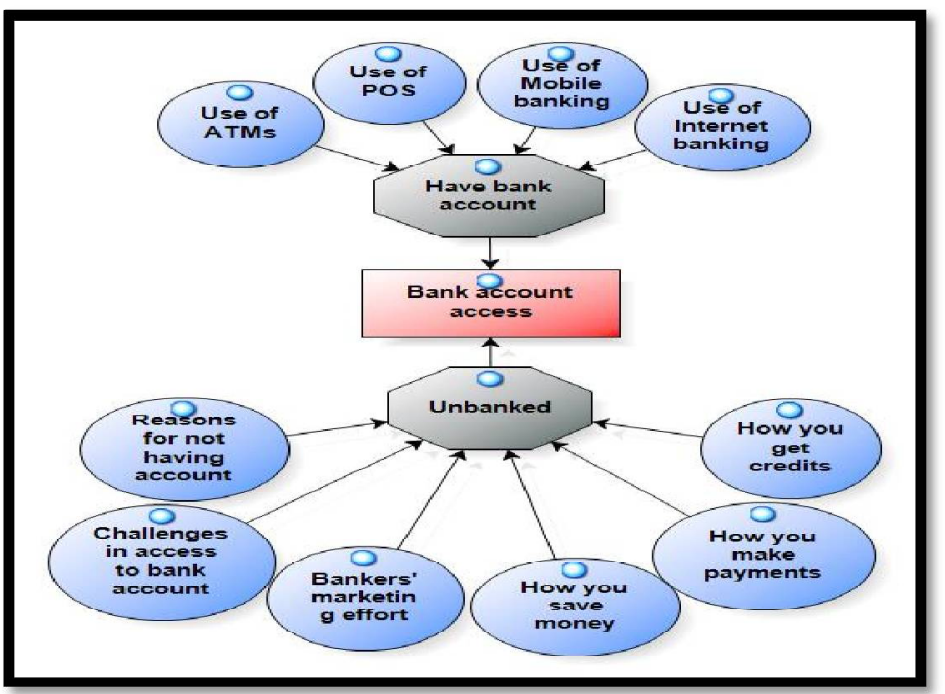

Figure 3: Access to Bank Account by Agribusiness Entrepreneurs

The following discussions were made with twelve (12) banked agribusiness entrepreneurs, to understand how they use modern payment terminals.

\subsection{Use of Automated Teller Machines (ATMs) for Bank Transactions}

Small-scale agribusiness entrepreneurs are highly using ATMs for transactions, it is found that, ten (10) out of twelve (12) account holders are using ATMs for cash withdrawal, transfers, airtime recharge or checking account balance, although, two are rare users, eight are frequent users of ATMs, only two entrepreneurs are completely not using ATMs, as shown in figure 4 below.

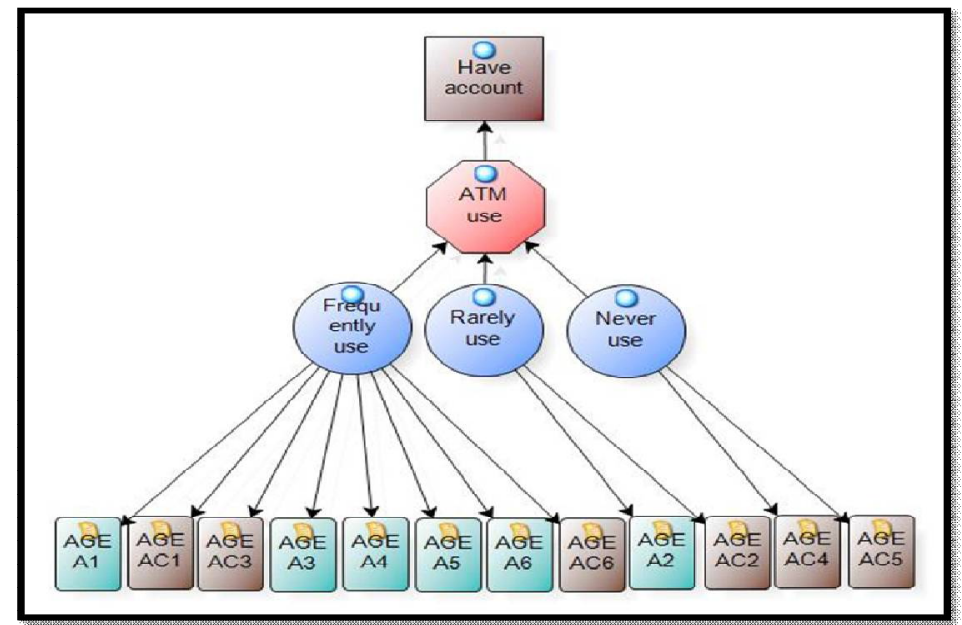

Figure 4: Use of ATMs by Account Holders

There is a high usage of ATMs among the entrepreneurs for various transactions, as shown by their responses in the figure above. Eight (8) out of the twelve entrepreneurs having bank account are frequently using ATMs for transactions. Their responses show that AGEA1, AGEA3, AGEA4, AGEA5, AGEA6, AGEAC1, AGEAC3, and AGEAC6 are frequently using ATMs for cash withdrawal, deposits, transfers, checking account balance and phone credit recharge.

Two informants (AGEA2 and AGEAC2) are rarely using ATMs. Their responses indicated that, they have ATM card, but rarely use it for cash withdrawal. AGEA2.

The only two (2) entrepreneurs that are not using ATMs are AGEAC4 and AGEAC5. AGEAC4 said he don't use ATMs, because of the problems of either waiting time on queues, dispense error, out of cash message, or connectivity problem. While AGEAC5 also said he have the card, he knew how to use it, but don't use it because his transactions are cash basis most of the time.

\subsection{Use of Point of Sales (POS) Machine and Agent Banking for Bank Transactions}

The case is different in POS usage, only one entrepreneur is using POS frequently, four (4) are rarely using it, and the remaining seven (7) are completely not using the machine. This is shown in figure 5 below. 


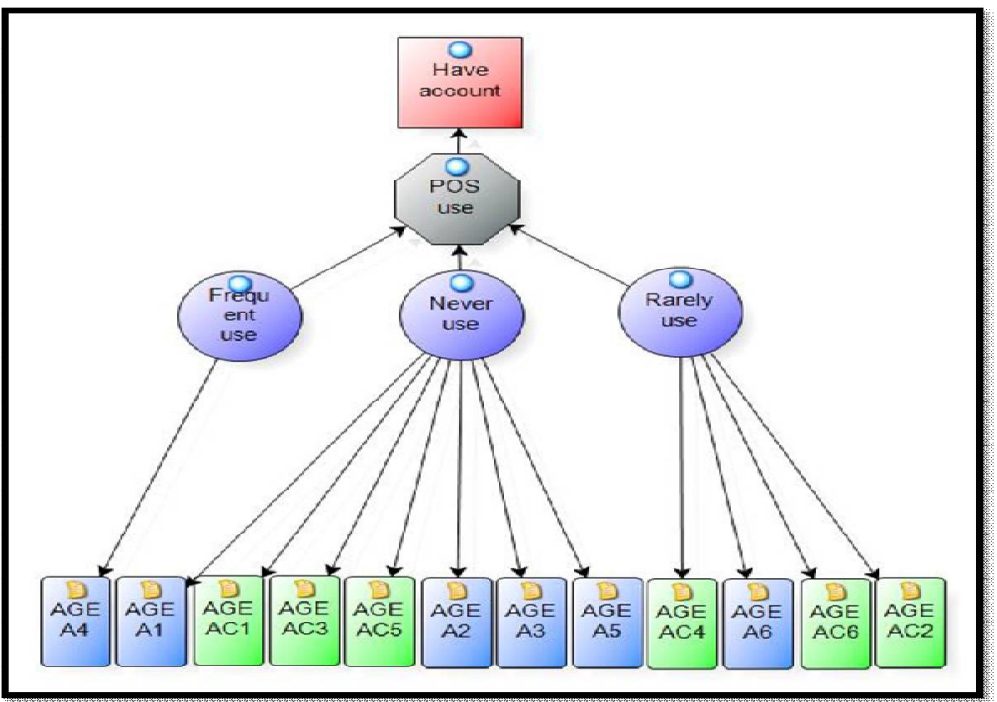

Figure 5: Use of POS by Account Holders

The only entrepreneur (AGEA4) using POS is making payment to one supplier, because he usually pays the dealer who sells farm chemicals to him, using card on his POS machine inside the dealer's shop.

Four entrepreneurs that occasionally use POS machine expresses they use it as follows; AGEA6 said when ATM machine did not give him cash or there is a long queue, he can go to someone's shop, make POS transfer to shop owner, and collect cash equivalent, but attracts little charges. AGEAC2 also said he use it sometimes for shopping. While AGEAC4 said, he like using it but, few traders have the machine in their shops, so he usually carries cash for my purchases. Finally, AGEAC6 said, he used it only one time in his life time, where he paid for some shopping in a provision store.

Majority (seven) of the informants never use POS machine for transactions in their life. AGEA1 said he knew P0S machine in shops, but, he never uses it. AGEA2 tried using it once for shopping, it was unsuccessful because of network failure, so he never tries using it again. AGEA3 and AGEA5 said they never use it and added that they never even try using it. AGEAC1 and AGEAC5 also said they never use it, just hearing about it. While AGEAC3 simply said, his suppliers don't have the machine.

\subsection{Use of Internet Banking Services}

The frequency of internet banking service' usage is also very low among small-scale agribusiness entrepreneurs. Only one entrepreneur is frequently using internet banking service, while other three (3) entrepreneurs are rarely using it. Majority (eight) of the entrepreneurs are not using and never use internet banking service for bank payment service, as shown in figure 6 below.

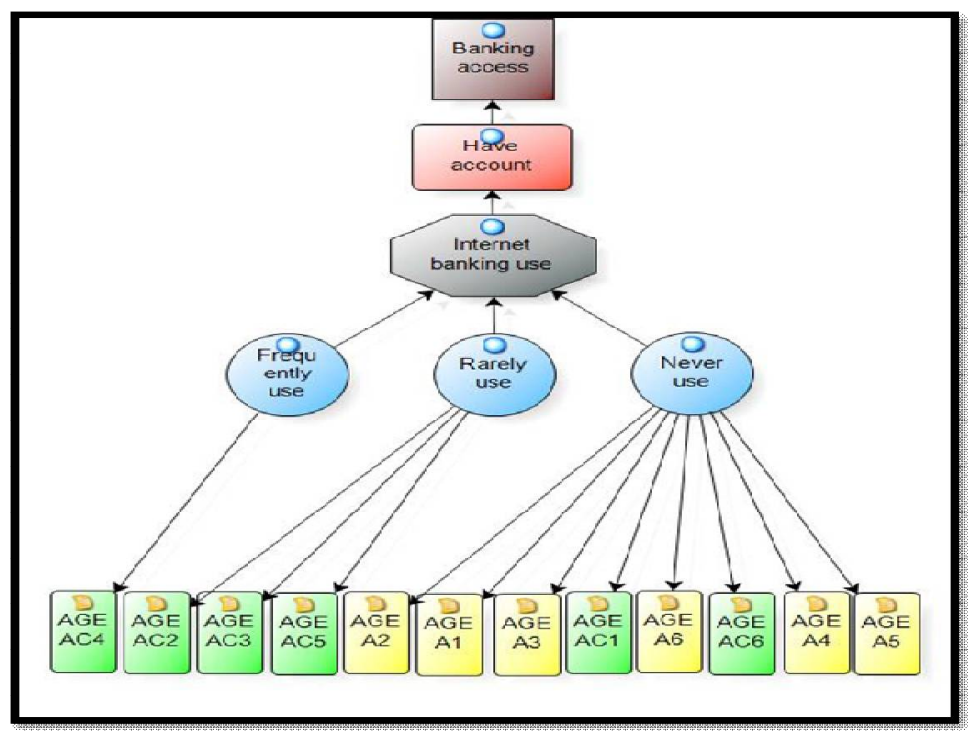

Figure 6: Use of Internet Banking by Account Holders

It is observed here that, only entrepreneurs accessing credits have experience of using internet banking, however, it may not be unconnected to their level of education. Although, some of the entrepreneurs among those not accessing credits has better level of education but not using internet banking.

The only entrepreneur using internet banking is AGEAC4, who says, he uses internet banking, and he feel comfortable and convenient using it, he used internet banking, on several occasions. 
Responses of AGEAC2, 3, and 5 indicates that they only occasionally use internet banking and found challenges in using it. AGEAC2, said he used it once, on recommendation of his account officer. AGEAC3 also said, he uses internet banking only for his account to account transfer. While, AGEAC5 added that, he sometimes makes transfer through internet banking with token number sent on mobile phone.

Majority of the entrepreneurs (eight) with bank account never use internet banking. AGEA1, AGEA2, AGEA3 and AGEA5 said they never use it and don't even know how it works. While AGEA4 added, that he never even attempted. But, AGEA6 and AGEAC1 said; they never use it, but they hear people talking about it. Finally, AGEAC6 knew how to use internet banking, but he never uses it.

\subsection{Use of Mobile Banking Services}

Likewise, the use of mobile banking for bank transactions is very unpopular among the entrepreneurs (except transaction alert), this is evidenced in the figure 7 below. Although three (3) entrepreneurs frequently use mobile banking. Only one (1) entrepreneur is found using mobile banking rarely. The majority (8) entrepreneurs never use mobile banking services, except for receiving transaction alerts. In this study, the researcher did not consider receiving transaction alert from one's account's transaction as mobile banking, because, receiving transaction alert is common and generally included in account opening criteria, virtually every customer receives transaction alert without a special request to activate it. After-all, it does not constitute any form of payment.

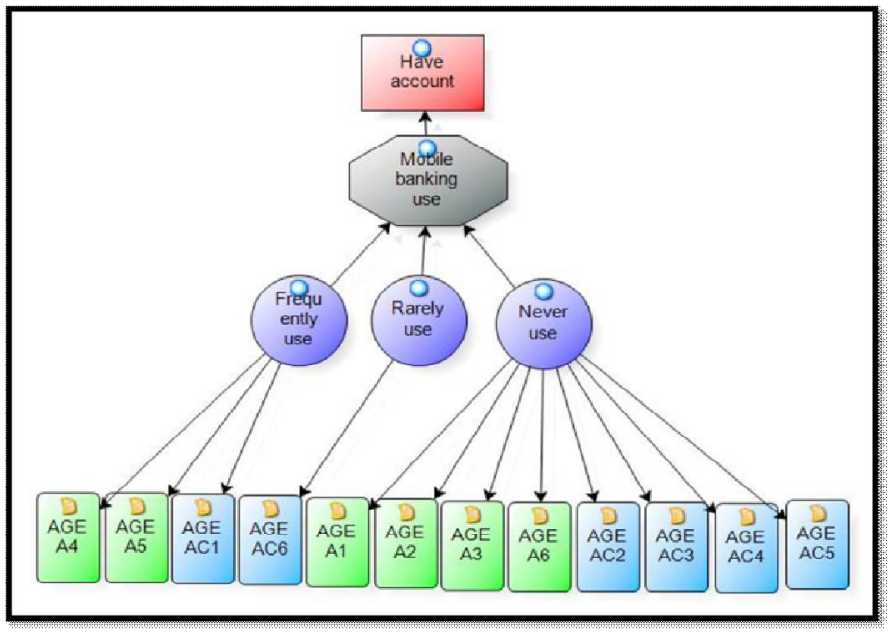

Figure 7: Use of Mobile Banking by Account Holders

The responses of these three (3) account holders show that they are frequently using mobile banking. AGEA4, and AGEA5 responded as saying that they can check account balance, and buy recharge card for self and others, using their mobile phone. While, AGEAC1 added that he sees bank balance, buy recharge card, receive transaction alert, and make cash transfer with his mobile smart phone.

The only entrepreneur that is rarely using mobile banking is AGEAC6, who said, he occasionally buys recharge card from his bank account using his mobile phone.

The remaining eight (8) informants that are not using mobile banking for any form of payment are AGEA 1, 2, 3 and 6, as well as AGEAC 2, 3, 4, and 5. Some of them responded that, they only receive transaction alert on their mobile phone, while others indicate that, in addition to transaction alert, they are checking account balance on their mobile phone. However, none of them makes any form of payment or transfer via mobile phone.

\section{Conclusion and Recommendations}

All informants having bank account are eligible to use various payment terminals like ATM, POS, internet, and mobile banking to transfer or withdraw money from their account. Therefore, use of various payment terminals by individuals with bank account were explored to assess the relationship of using modern payment terminal with bank account status. Table 1 below summarised extent of the overall use of payment terminals based of bank account status (banked but not accessing credits and those accessing credits) by all informants that has bank account, as shown in table 1 and figure 8 below: 


\begin{tabular}{|c|c|c|c|c|c|c|}
\hline & \multicolumn{2}{|c|}{ Never Use } & \multicolumn{2}{c|}{ Rarely Use } & \multicolumn{2}{c|}{ Frequently Use } \\
\hline & $\begin{array}{c}\text { Banked } \\
\text { but no } \\
\text { credits }\end{array}$ & $\begin{array}{c}\text { Banked and } \\
\text { Access } \\
\text { credits }\end{array}$ & $\begin{array}{c}\text { Banked } \\
\text { but no } \\
\text { credits }\end{array}$ & $\begin{array}{c}\text { Accessing } \\
\text { credits }\end{array}$ & $\begin{array}{c}\text { Banked } \\
\text { but no } \\
\text { credits }\end{array}$ & $\begin{array}{c}\text { Accessing } \\
\text { credits }\end{array}$ \\
\hline ATM use & 0 & 2 & 1 & 1 & 5 & 3 \\
\hline POS use & 4 & 3 & 1 & 3 & 1 & 0 \\
\hline $\begin{array}{c}\text { Internet } \\
\text { banking use }\end{array}$ & 6 & 2 & 0 & 3 & 0 & 1 \\
\hline $\begin{array}{c}\text { Mobile } \\
\text { banking use }\end{array}$ & 4 & 4 & 0 & 1 & 2 & 1 \\
\hline
\end{tabular}

Table 1: Entrepreneurs' Usage of Payment Terminal by Banking Status

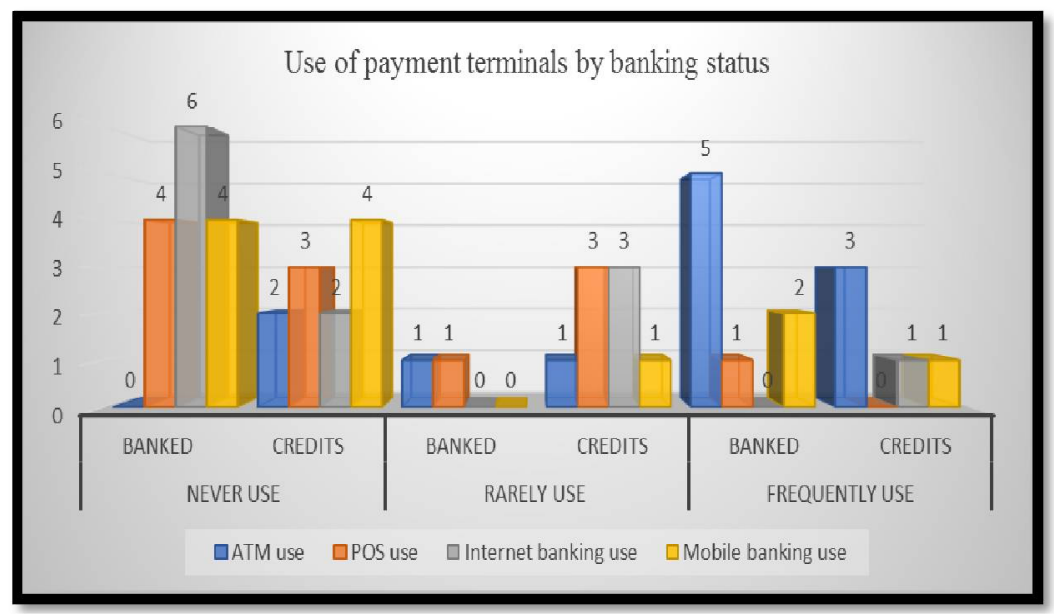

Figure 8: Entrepreneurs' Usage of Payment Terminal by Banking Status

Nevertheless, there is no difference or superiority noticed in use of payment terminals among banked entrepreneurs accessing credits and those not accessing credits. In some cases, entrepreneurs not accessing credits use payment terminals more than those accessing credits, depending on entrepreneur's literacy level, and in some other cases, is vice versa. This show that, access to credit has no relationship with use of payment terminals by banked entrepreneurs. Generally, entrepreneurs with bank account are frequently using ATMs for cash withdrawal and other services. But, there is poor use of POS, internet, and mobile banking services among small agribusiness entrepreneurs. This is justified by responses of banked entrepreneurs, where majority are frequently using ATMs, and majority of them never use POS, internet, and mobile banking for payments. However, this may be associated with the nature of Nigerian economy which has more cash transactions than electronic payment system. The recent cashless policy introduced by CBN across all states of Nigeria may likely reduce use of cash transactions (Aborisade, 2014).

There is no difference in use of electronic payment terminals among entrepreneurs with Islamic and conventional bank account. There is also no difference or superiority noticed in use of payment terminals among banked entrepreneurs accessing credits and those not accessing credits. But there is association of use of payment system terminals and level of education of the entrepreneurs. This show that, access to credit has no relationship with use of payment terminals by banked entrepreneurs but use of banking payment terminals is associated with level of education (financial literacy). Despite level of education (financial literacy), there are challenges that affects entrepreneurs' use of payment terminals. This relationship is shown in figure 9 below.

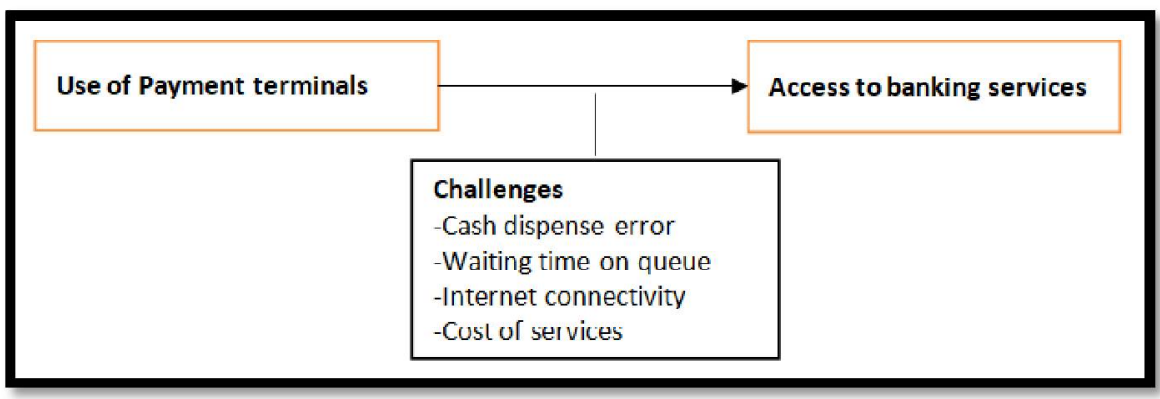

Figure 9: Relationship of Using Payment Terminals with Financial Literacy

Therefore, it is recommended that banks should take care of the intermittent cash dispense error by ATMs. This can be done by making the machine more user friendly and by inserting clean bank notes. Banks are also expected to install many ATMs in various locations of main towns and cities. Many installed machines are out of cash for several times. Therefore, bank managers need to be proactive in handling and loading cash to ATMs. Internet connectivity need to be 
strong and fast to enable users of payment terminals effective and efficient transaction. Bankers also need to reconsider charges on using payment terminals. Many users complained that, the cost of services is too much.

\section{References}

i. Abiara, S. J., \& Arosanyin, G. T. (2014). Evaluation of Small-Scale Enterprises' Financing Options in Ilorin, Nigeria. Comprehensive Research Journal of Management and Business Studies (CRJMBS) Vol. 2 (1) pp. 011 - 017

ii. Akenbor, C. O., (2015). Financial inclusion and poverty trap in Nigeria, Mustang Journal of

iii. Accounting and Finance. Volume 7 (2015), 149

iv. Alabi, O. O., Lawal, A. F., \& Chiogor, H. (2016). Access to formal credit facilities small scale crop farmers in Gwagwalada area council, Abuja, Nigeria. Russian Journal of Agricultural and Socio-Economic Sciences, 1(49), 5766.

v. Amidzic, G., A. Massara, and A. Mialou, (2014). Assessing Countries' Financial Inclusion Standing - A New Composite Index. IMF Working Papers 14/36. Washington, DC: International Monetary Fund.

vi. Asongu, S. A., \& De Moor, L. (2015). Recent advances in finance for inclusive development: a survey. AGDI $\mathrm{WP} / 15 / 005$

vii. Beck, T., Demirgu-Kunt, A., (2008). Advance Access to Finance. The World Bank Economic Review, VOL. 22, No. 3, pp. 383 -396 November 7, 2008. Published by Oxford University Press, available: worldbank.org.doi:10.1093/

viii. Beck, T., Demirguc-Kunt, A., \& Hanohap M. (2008). Reaching out: Access to and use of banking services across countries. Journal of Financial Economics, 85(1), 234- 266.

ix. Clementina, K., \& Egwu, C. K. (2015). Financial exclusion of small and medium enterprise and poverty alleviation: Nigeria experience, Archives of business research, 3(4).

x. Creswell, J. W. (2012). Educational research: Planning, conducting, and evaluating quantitative. 4th ed. Pearson.

xi. Creswell, J. W. (2013) Qualitative Inquiry and Research Design: Choosing among Five Approaches, 3rd edition, Thousand Oaks, CA: Sage.

xii. EFInA Survey report, (2016). Access to financial service survey. CBN, Abuja, Nigeria. Available at efina.org.ng

xiii. Egbide, B. C., Samuel, F., Babajide, O., \& Samuel, F. (2015). What financial inclusion in Nigeria should include. American Journal of Scientific Advances, 1(1), 36-42.

xiv. Jahiou, R. (2013). Financial inclusion: What is it all about? Financial Policy Review; Issue 71; 36-44

xv. Malaguti, M. C. (2015). Payment System Regulation for Improving Financial Inclusion. Washington, DC: Center for Global Development. Policy paper 070, 2015.

xvi. Marshal, C., \& Rossman, G. B. (1999). Designing qualitative research (3rd ed.). Thousand OIaks, CA: Sage.

xvii. NFIS Annual Report, (2015), Annual Report of National Financial Inclusion Strategy, the Secretariat, CBN.

xviii. Rao, K. S., \& Baza, A. U. (2015). Role of commercial bank of Ethiopia in financial inclusion.

xix. Richard Aborisade, (2014). The Future of Consumer Payments in Nigeria: An Evaluation of the E-Payment System Vision-2020. Journal of Emerging Trends in Computing and Information Sciences. Vol. 5, No.3 